\title{
Thermotherapy in treating fennel seeds (Foeniculum vulgare Mill.): effects on health and physiological quality ${ }^{1}$
}

\author{
Termoterapia no tratamento de sementes de erva-doce (Foeniculum vulgare Mill.): \\ efeito sobre a qualidade fisiológica e sanitária
}

\author{
Juliana Simões Nobre Gama ${ }^{2 *}$, Aderson Costa Araujo Neto ${ }^{3}$, Riselane de Lucena Alcântara Bruno ${ }^{4}$, Lécio \\ Resende Pereira Júnior ${ }^{5}$ e José George Ferreira Medeiros ${ }^{6}$
}

\begin{abstract}
Thermotherapy is a physical treatment consisting of the exposure of seeds to the action of heat over time. The aim was to assess the health and physiological quality of fennel seeds (Foeniculum vulgare Mill.), both freshly harvested and stored for three years, and submitted to thermotherapy. Two experiments were conducted. In the first, thermotherapy was carried out on freshly-harvested fennel seeds obtained under different cropping systems: T1 - Monocrop fennel treated with the insecticide, thiamethoxam; T2 - Monocrop fennel without the application of insecticide; T3 - Fennel intercropped with cotton and treated with insecticide; T4 - Intercropped fennel without the application of insecticide. In the second experiment, seeds were used which had been stored for three years and obtained from plants, both treated and untreated with insecticide. The seeds were exposed to dry heat for different periods $\left(0,3,6,9,12\right.$ and 15 days) at $70{ }^{\circ} \mathrm{C}$. The tests performed included: health, germination, first count, speed germination index, seedling length and dry weight. The cropping systems had no influence on the incidence of the fungus Alternaria sp. Stored fennel seeds coming from plants treated with insecticide, display better health and physiological quality. A period of 12 days of thermotherapy is effective in controlling the fungus Alternaria sp. without causing losses in the viability of the fennel seeds.
\end{abstract}

Key words: Alternaria sp. Thiamethoxam. Vigour.

RESUMO - A termoterapia é um tratamento físico, que consiste na exposição das sementes à ação do calor em combinação com o tempo. Objetivou-se avaliar a qualidade sanitária e fisiológica de sementes de erva-doce (Foeniculum vulgare Mill.), recém-colhidas e armazenadas por três anos, submetidas à termoterapia. Foram conduzidos dois experimentos: no primeiro, a termoterapia foi realizada com sementes de erva-doce recém-colhidas obtidas de diferentes sistemas de plantio: T1 - erva-doce solteira tratada com inseticida thiamethoxam; T2 - erva-doce solteira sem aplicação do inseticida; T3 - erva-doce consorciada com algodão e tratada com inseticida; T4 - erva-doce consorciada sem aplicação do inseticida. No segundo experimento utilizaram-se sementes armazenadas por três anos obtidas de plantas tratadas e não tratadas com inseticida. As sementes foram submetidas a diferentes tempos de exposição ao calor seco $\left(0 ; 3 ; 6 ; 9,12\right.$ e 15 dias) a $70{ }^{\circ} \mathrm{C}$. Os testes realizados foram: sanidade, germinação, primeira contagem, índice de velocidade de germinação, comprimento e massa seca de plântulas. Os sistemas de plantio não influenciaram na incidência do fungo Alternaria sp. As sementes de erva-doce armazenadas, oriundas de plantas tratadas com inseticida, possuem maior qualidade sanitária e fisiológica. O período de 12 dias de termoterapia é eficiente no controle do fungo Alternaria sp. sem proporcionar perdas na viabilidade das sementes de erva-doce.

Palavras-chave: Alternaria sp. Thiamethoxam. Vigor.

\footnotetext{
*Autor para correspondência

${ }^{1}$ Recebido para publicação em 06/12/2013; aprovado em 27/06/2014

Parte da Dissertação de Mestrado apresentada no Centro de Ciências Agrárias da Universidade Federal da Paraíba

${ }^{2}$ Programa de Pós-Graduação em Ciência e Tecnologia de Sementes, Universidade Federal de Pelotas, Pelotas-RS, Brasil, julianasimoes22@ yahoo.com.br

${ }^{3}$ Programa de Pós-Graduação em Agronomia, Universidade Estadual do Sudoeste da Bahia, Vitória da Conquista-BA, Brasil, aderson_biologo@ hotmail.com

${ }^{4}$ Departamento de Fitotecnia, Universidade Federal da Paraíba, Areia-PB, Brasil, lanebruno.bruno@ gmail.com

${ }_{5}^{5}$ Programa de Pós-Graduação em Ecologia e Recursos Naturais, Universidade Federal do Ceará, Fortaleza-CE, Brasil, leciojunior@ hotmail.com

${ }^{6}$ Programa de Pós-Graduação em Agronomia, Universidade Federal da Paraíba, Areia-PB, Brasil, georgemedeiros_jp@ @otmail.com
} 


\section{INTRODUCTION}

Fennel (Foeniculum vulgare Mill.) belongs to the Apiace a family, and has aromatic, flavouring and medicinal properties; it can be used in alternative medicine as well as in the cosmetic industry (CHOI; HWANG, 2004) due to its essential oil which is rich in various biologically active ingredients (SOUSA et al., 2005).

Seeds are an efficient means of transmitting pathogens, often introducing them into previously noninfected areas. The presence of pathogens can reduce the physiological quality of the seeds; the integration of tests for the health and physiological quality of the seeds is therefore recommended (LAZAROTTO et al., 2013).

The level of deterioration in stored seeds depends on the conditions of the batch at the start of storage and the control of environmental factors during this phase. In seeds, the elimination or reduction of the infective inoculant of fungi has been efficiently achieved through chemical, biological and physical treatments (ESTEFANI; MIRANDA FILHO; UESUGI, 2007). Among the physical methods, the effectiveness of thermotherapy, which consists of exposing the seeds to the action of heat combined with the time of treatment, has been demonstrated in some studies (CARMO et al., 2004; LOPES; ROSSETTO, 2004; OLIVEIRA et al., 2011). However, for this method to be successful, it is necessary to know the correct combination of temperature and exposure time, which may vary with the species, cultivar, batch, initial vigour and other factors.

The technique of using thermotherapy for controlling fungi transmitted by seeds has shown promising results. By means of this therapy several pathogens have been controlled and/or eradicated, including Fusarium oxysporum in alfalfa seeds (MENDES et al., 2001), Xanthomonas campestris pv. Vesicatoria in tomato seeds (SILVA et al., 2002) and Fusarium verticillioides in maize seeds (COUTINHO et al., 2007). Thermotherapy has also considerably reduced fungi that contaminate the seed surface thereby increasing their vigour (MUNIZ, 2001) and power of germination (BRAGA et al., 2010).

Given the above, the aim was to assess the health and physiological quality of fennel seeds obtained under different growing systems and submitted to thermotherapy, both when newly harvested and after three years of storage.

\section{MATERIAL AND METHODS}

The study was carried out in the Seed Analysis and Plant Pathology Laboratory of the Centre for Agrarian Sciences at the Federal University of Paraíba, in Areia, in the state of Paraíba, Brazil (PB). The fennel seeds were harvested in an experimental area located in the town of Lagoa Seca, PB (7'10'15" S and 35 51 ' 14 "' W), and collected from the following plants: T1 - monocrop treated with the insecticide thiamethoxam (M-TR); T2 - monocrop without the application of insecticide (M-NT); T3 - intercropped with cotton cv. BRS Safira and treated with the insecticide thiamethoxam (I-TR); and T4 - intercropped without the application of insecticide (I-NT).

One sample of the seeds was packed in plastic bags and stored in a refrigerator $\left(10{ }^{\circ} \mathrm{C}\right.$ and $\left.60 \% \mathrm{RH}\right)$ and another sample was used in the thermotherapy tests. For this, samples of $5 \mathrm{~g}$ of seeds taken from each treatment were placed into gauze bags $(20 \times 20 \mathrm{~cm})$ and submitted to six periods of heat exposure $(0,3,6,9,12$ and 15 days) in a forced air oven at $70{ }^{\circ} \mathrm{C}$, giving a total of 24 treatments. After each period, the samples were removed from the oven, packed into aluminium capsules and placed in a desiccator to standardise the moisture content and gradually cool the seeds.

The efficiency of the treatments was evaluated by two tests: a) Germination - four replications of 25 seeds were sown in acrylic boxes (Gerbox), 11.0 x $11.0 \times 3.0 \mathrm{~cm}$, containing blotting paper moistened with 2.5 times its dry weight, and kept in a Biochemical Oxygen Demand (BOD) germinator at an alternating temperature of $20 / 30{ }^{\circ} \mathrm{C}$ (BRAZIL, 2009). Counts of germinated seeds were taken daily until the 14th day after sowing when the water content of the seeds was determined by the oven method at $105 \pm 3{ }^{\circ} \mathrm{C}$ for 24 hours (BRAZIL, 2009); b) Health - this was assessed using the blotter test (NEERGAARD, 1977), employing five replications of 20 seeds per treatment, placed in Petri dishes containing a double layer of filter paper previously moistened with sterile distilled water (SDW). The dishes were then placed in an incubation chamber at $24 \pm 2{ }^{\circ} \mathrm{C}$ under an alternating regime of 12 hours light/12 hours darkness for seven days (BRAZIL, 2009). After this period the fungi associated with the seeds were counted and identified with the aid of a stereoscopic microscope. The results were expressed as a percentage of fungus incidence per replication.

The second experiment was carried out on the seeds which had been stored for three years, coming both from plants treated (TR) and not treated (NT) with the insecticide thiamethoxam. Samples of $5 \mathrm{~g}$ of seeds from each treatment were placed into gauze bags and submitted to six periods of heat exposure $(0,3,6,9,12$ and 15 days) at $70{ }^{\circ} \mathrm{C}$, giving a total of 12 treatments. The water content of the seeds was determined and the health test carried out as previously described. Evaluation of physiological quality was performed as per the described variables: a) Germination - four replications of 25 seeds were sown in acrylic boxes (Gerbox), 11.0 x $11.0 \times 3.0 \mathrm{~cm}$, containing blotting paper moistened with 2.5 times its dry weight and 
kept in a BOD germinator at an alternating temperature of $20 / 30{ }^{\circ} \mathrm{C}$ (BRAZIL, 2009); b) First germination count - the cumulative percentage of normal seedlings on the seventh day after sowing, considering as normal any seedlings having perfect essential structures (BRAZIL, 2009); c) Speed of germination index (SGI) - determined by the daily count of normal seedlings, with the index being calculated using the formula proposed by Maguire (1962); d) Seedling length - at the end of the test for germination, the seedlings were measured (from the root to the cotyledon insertion) with the aid of a rule graduated in centimetres, and the results expressed in centimetres per seedling; e) Seedling dry weight - after measuring the plants, they were put into bags made from kraft paper and placed into a forced air circulation oven at $65{ }^{\circ} \mathrm{C}$, where they remained until reaching constant weight. They were then weighed by analytical balance accurate to $0.0001 \mathrm{~g}$, and the results expressed in milligrams per seedling.

The experimental design was completely randomised; in the first experiment the treatments were arranged in a 4 x 6 factorial (four cropping systems $x$ six periods of thermotherapy) and in the second experiment, in a 2 × 6 factorial (treated and untreated seeds $\times$ six periods of thermotherapy). The data were submitted to variance analysis and the means were compared by Tukey test at $5 \%$ probability. Polynomial regression analysis was performed, selecting the significant models $(\mathrm{F} \leq 0.05)$ for $\mathrm{R}^{2} \geq 60 \%$.

\section{RESULTS AND DISCUSSION}

In health tests for the newly-harvested fennel seeds, some genera of fungi were identified, but at a very low frequency, such as: Aspergillus sp., Cladosporium sp. and Rhizopus sp. However, the genus Alternaria sp. was seen at a higher frequency in this crop, and will be given greater emphasis.
In Table 1 can be seen the ANOVA summary of the health and physiological quality of newly-harvested fennel seeds under different cropping systems and submitted to thermotherapy (Experiment 1).

It can be seen that the initial infestation of the seed samples was over $80 \%$ for all the cropping systems evaluated (Figure 1). However, there is a tendency for this to decrease with the increase in the number of days the seeds are exposed to heat. The incidence of Alternaria sp. after 15 days exposure was almost zero for the I-NT (1A), I-TR (1B) and M-TR (1D) systems, and at 9 days it was more than $50 \%$ under control (Figure 1). A less-marked reduction was seen for the M-NT (1C) system compared to the others, this may have occurred due to the absence of intercropping and insecticide resulting in greater development of the fungus in this batch of seeds. It should be noted however that thermotherapy was effective in controlling Alternaria sp. associated with the fennel seeds.

Evaluating thermotherapy in carrot seeds, Trigo et al. (1998b) also found that the process became more efficient with increasing periods of heat exposure. Using thermotherapy in the control of Xanthomonas campestres in tomato seeds, direct action by the heat was seen on the structure of the bacteria, which exhibited loss of cell integrity and signs of drying (SILVA et al., 2002).

According to the data in Table 2, which refers to the percentage of germination in the newly-harvested fennel seeds after different periods of heat exposure, it can be seen that for the period of 0 days (control), germination was $\leq 70 \%$ for all cropping systems. However, at 15 days the percentages were over $70 \%$, except for the intercropped, untreated system (I-NT), which was statistically similar to the control. It can therefore be seen that a period of fifteen days was not only effective in controlling Alternaria sp., but had no adverse effects on seed viability.

Table 1 - Variance analysis summary of the incidence of Alternaria sp. and the germination of newly-harvested seeds of Foeniculum vulgare from different cropping systems and submitted to thermotherapy

\begin{tabular}{lccc}
\hline \multirow{2}{*}{ S.V. } & DF & Alternaria $\mathrm{sp}$. & Germination \\
\cline { 3 - 4 } & & $4,117.25^{* *}$ & $2,332.78^{* *}$ \\
\hline CS & 3 & $11,450.26^{* *}$ & $2,241.71^{* *}$ \\
PER & 5 & $968.98^{* *}$ & $3,356.32^{* *}$ \\
CS*PER & 15 & 323.58 & 20.165 \\
Residual & 69 & 36.6 & 8.10 \\
\hline CV $(\%)$ & & PEn
\end{tabular}

$\mathrm{SV}=$ Source of variation; $\mathrm{DF}=$ Degree of freedom; CS = Cropping system; PER = Period of thermotherapy. Values significant at $1 \%(* *)$ e at $5 \%(*)$; ns - Not significant 
Figure 1 - Percentage of Alternaria sp. in seeds of Foeniculum vulgare from different cropping systems and submitted to different periods of thermotherapy. Where: (A) I-NT: intercrop - untreated; (B) I-TR: intercrop - treated; (C) M-NT: monocrop - untreated and (D) M-TR: monocrop - treated
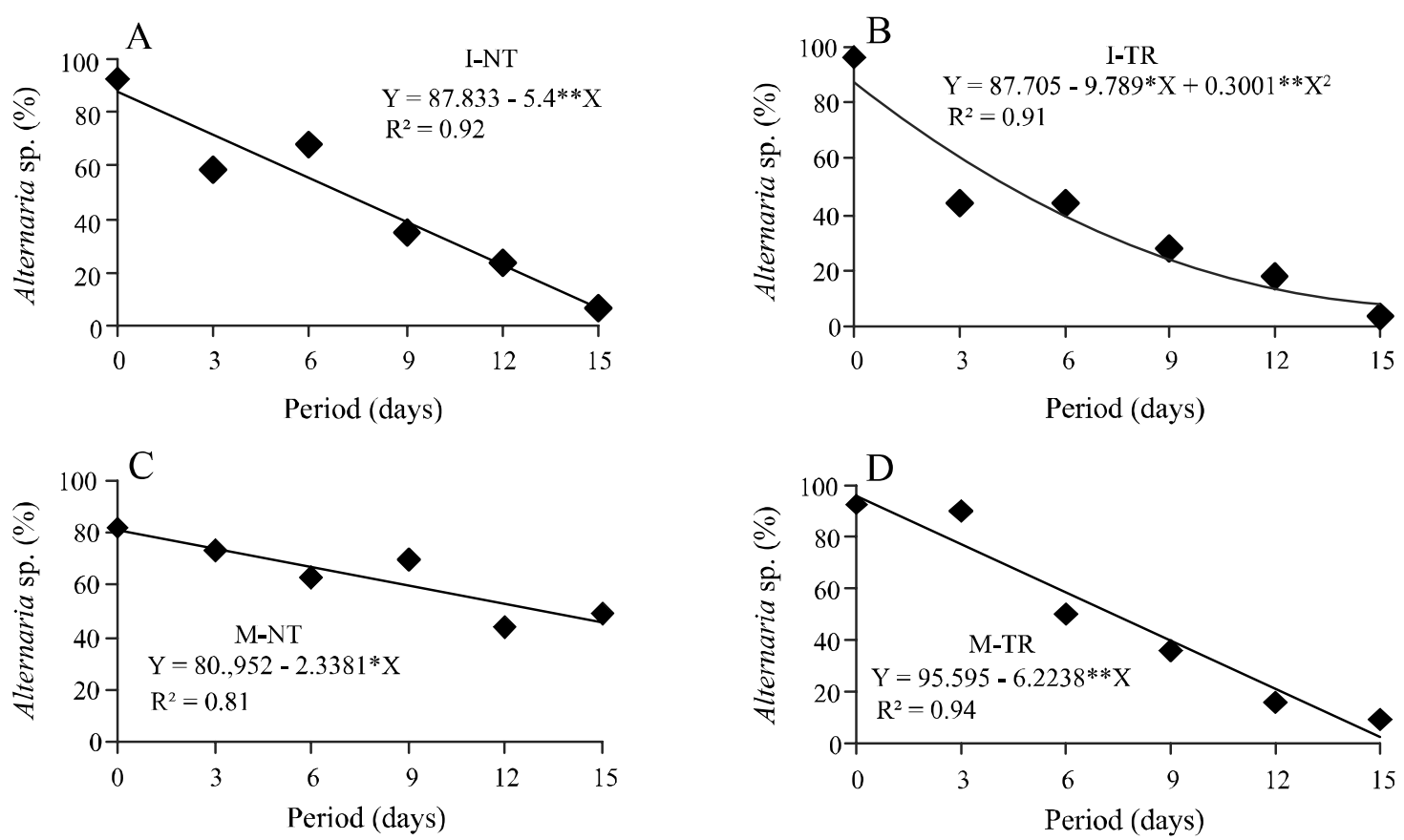

Table 2 - Germination (\%) in seeds of Foeniculum vulgare from different cropping systems and periods of thermotherapy

\begin{tabular}{llllc}
\hline \multirow{2}{*}{ Period } & \multicolumn{3}{c}{ Cropping system } \\
\cline { 2 - 5 } & I-NT & I-TR & M-NT & M-TR \\
\hline 0 & $60 \mathrm{bB}$ & $37 \mathrm{dC}$ & $70 \mathrm{bA}$ & $8 \mathrm{fD}$ \\
3 & $29 \mathrm{dC}$ & $82 \mathrm{cB}$ & $91 \mathrm{aA}$ & $32 \mathrm{eC}$ \\
6 & $68 \mathrm{aB}$ & $31 \mathrm{dC}$ & $16 \mathrm{dD}$ & $90 \mathrm{aA}$ \\
9 & $12 \mathrm{eD}$ & $24 \mathrm{eC}$ & $86 \mathrm{aA}$ & $64 \mathrm{cB}$ \\
12 & $38 \mathrm{cD}$ & $84 \mathrm{bA}$ & $58 \mathrm{cB}$ & $49 \mathrm{dC}$ \\
15 & $55 \mathrm{bC}$ & $91 \mathrm{aA}$ & $83 \mathrm{aB}$ & $79 \mathrm{bB}$ \\
\hline
\end{tabular}

Averages followed by the same letter, uppercase on a line and lowercase in a column, do not differ significantly by Tukey test at $5 \%$ probability

Carrot seeds of high physiological quality can be treated with dry heat $\left(70{ }^{\circ} \mathrm{C} / 15\right.$ days $)$ without immediate impairment of germination or vigour (TRIGO et al., 1998b). However, for seeds of the mulungo, heat treatment was not found to be promising in the control of detected fungi, as it affected the physiological quality of the seeds (OLIVEIRA et al., 2009).

Table 3 shows the ANOVA summary of the health and physiological quality of fennel seeds harvested from plants treated (TR) and not treated(NT) with thiamethoxam, stored for three years and submitted to thermotherapy
(Experiment 2). In the interaction of this condition (TR and NT) with the periods of thermotherapy, significance can be seen for all the tested variables, except for speed of germination index (SGI) and seedling length; isolated effects from these factors however can be observed.

Figure 2 shows data for the incidence of Alternaria sp. (\%) in stored fennel seeds from plants both treated (TR) and not treated (NT) with thiamethoxam, for different periods of thermotherapy. The conditions NT and TR exhibited similar behaviour during the periods of thermotherapy, with a reduction 
Table 3 - Summary of variance analysis for the incidence of Alternaria sp. (ALT), water content (CW), germination (G), first count (FC), speed of germination index (SGI), length (LN) and seedling dry weight (DW) in stored seeds of Foeniculum vulgare, from plants treated and not treated with insecticide, and submitted to different periods of thermotherapy

\begin{tabular}{lcccccccc}
\hline \multirow{2}{*}{ S.V. } & \multirow{2}{*}{ DF } & \multicolumn{8}{c}{ Mean square } \\
\cline { 2 - 9 } & & ALT & CW & G & FC & SGI & LN & DW \\
\hline COND & 1 & $1,260.41^{* *}$ & $15.21^{* *}$ & $7,008.3^{* *}$ & $4,720.33^{* *}$ & $7.12^{* *}$ & $7.56^{* *}$ & $49.45^{* *}$ \\
PER & 5 & $8,521.75^{* *}$ & $19.95^{* *}$ & $665.13^{* *}$ & $968.6^{* *}$ & $0.87^{* *}$ & $13.37^{* *}$ & $8.85^{* *}$ \\
COND*PER & 5 & $358.41^{* *}$ & $1.56^{* *}$ & $39.53^{*}$ & $391.93^{* *}$ & $0.10^{\text {ns }}$ & $0.73^{\text {ns }}$ & $0.38^{* *}$ \\
Residual & 33 & 91.64 & 0.03 & 11.16 & 65.78 & 0.07 & 0.37 & 0.03 \\
\hline CV $(\%)$ & & 24.08 & 2.38 & 7.28 & 23.68 & 17.57 & 10.71 & 6.05 \\
\hline
\end{tabular}

$\mathrm{SV}=$ Source of variation; DF $=$ Degree of freedom; COND = Condition (treated or untreated); PER = Period of thermotherapy. Values significant at $1 \%(* *)$ e at $5 \%(*)$ by F-test; ${ }^{\text {ns }}$ - Not significant

Figure 2 - Incidence of Alternaria sp. in the stored seeds of Foeniculum vulgare, from plants treated (TR) and not treated (NT) with insecticide and submitted to different periods of thermotherapy

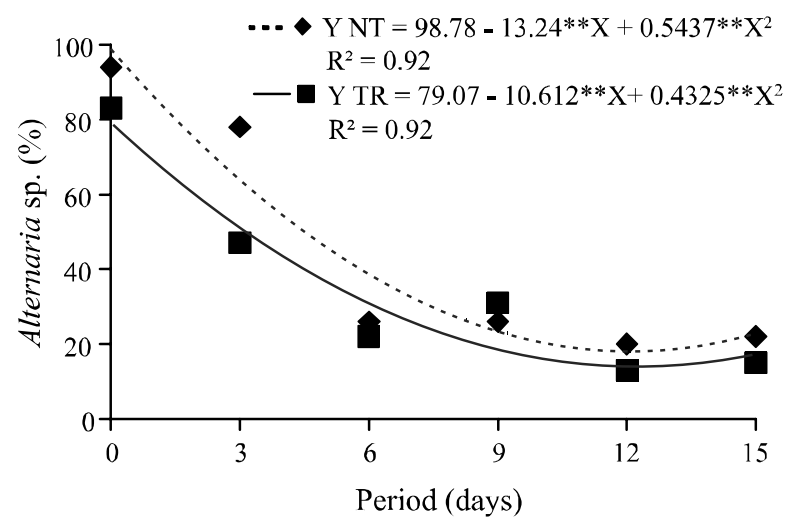

in the incidence of Alternaria sp. up to the 12 th day, when the lowest values (18 and 14\% respectively) were observed. However, after this period there was a slight increase in incidence up to the 15 th day of treatment for both conditions (22.36 and $17.2 \%$, respectively), with the highest incidence being recorded for the control period of 0 days of thermotherapy (98.8 and $79.07 \%$ respectively).

The genus Alternaria sp. is often associated with seeds of the Apiacea family. Gama et al. (2012) observed that the physiological quality of fennel seeds was affected mainly by the genus Alternaria sp., which, despite not being considered a fungus of importance during storage, is seen as persistent, even in seeds stored for three years, remaining at very high levels when compared to tests carried out on newly-harvested seeds. This fungus can also be destructive to the carrot, cilantro (REIS et al., 2006) and parsley (PEDROSO et al., 2010).
In relation to the water content of stored fennel seeds (Figure 3), a reduction in the percentage of moisture was seen with the increasing periods of exposure to heat. The highest percentages of moisture obtained initially were 9.4 and $12.4 \%$, and the lowest at 15 days of heat exposure (5.8 and $6.4 \%$ in seeds of NT and TR plants respectively). Trigo et al. (1998a) also noted a considerable reduction in the water content of carrot seeds with increasing periods of thermotherapy.

Figure 3 - Water content of stored seeds of Foeniculum vulgare, from plants treated (TR) and not treated (NT) with insecticide and submitted to different periods of thermotherapy

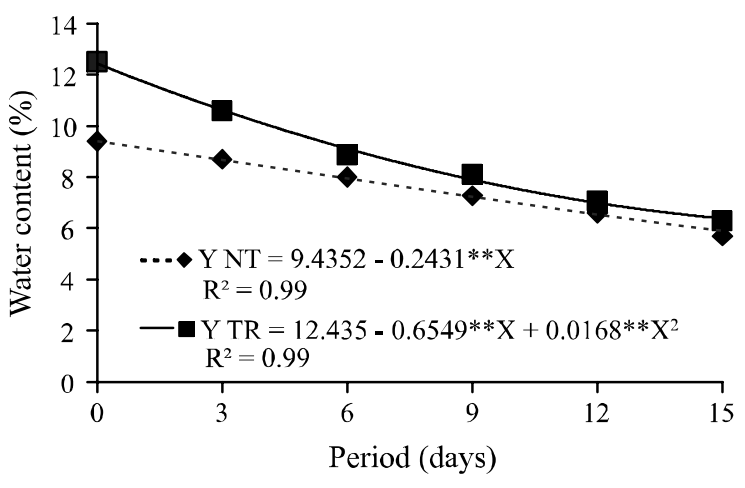

From Figure 4 it can be seen that the highest percentages of germination were obtained in seeds from treated plants (TR) for all periods of thermotherapy. For the conditions NT and TR, there was an increase in germination up to 7.3 and 7.9 days respectively, when the highest percentages were recorded (42 and 69\% respectively). After this period, there was a reduction 
in the percentage of germination up to the 15 th day of treatment (23 and $49 \%$ respectively), when the lowest percentage of germination was found for the seeds of untreated plants. The smallest percentage for the seeds of treated plants was recorded for the control period of 0 days of thermotherapy (43\%).

Figure 4 - Germination (\%) in stored seeds of Foeniculum vulgare, from plants treated (TR) and not treated (NT) with insecticide and submitted to different periods of thermotherapy

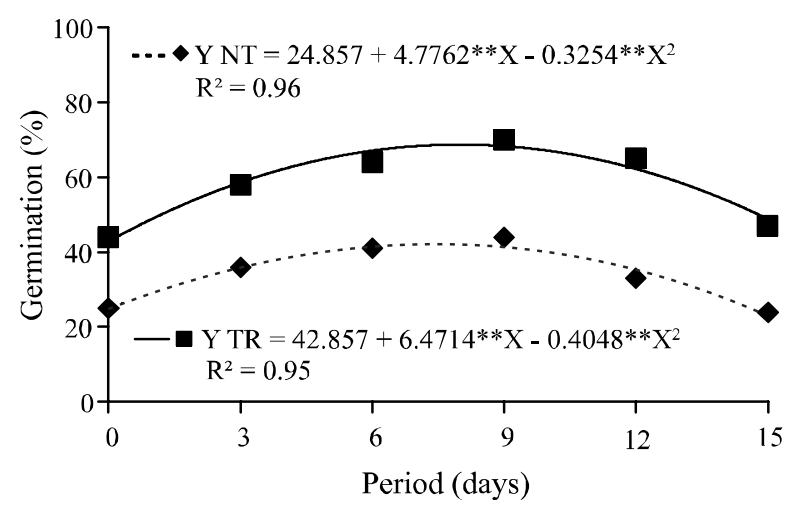

It is worth noting however that the response of seeds to a combination of the factors time and temperature may vary from species to species, cultivar to cultivar and often from batch to batch. Coutinho et al. (2007) found that increasing the time of heat treatment decreased the percentage of normal seedlings, resulting finally in the complete loss of germination capacity, at $60{ }^{\circ} \mathrm{C}$ for 20 minutes, in maize seeds. Braga et al. (2010) concluded that heat treatment $\left(55^{\circ} \mathrm{C}\right.$ for $\left.30 \mathrm{~min}\right)$ is a sound option in the control of the fungi Rhizopus sp., Aspergillus sp. and Cladosporium sp. in the tomato, without harming the physiological potential of the seeds.

In assessing first germination (Figure 5), the highest percentages were observed at 9 days, with $29 \%$ for the seeds of untreated plants and $60 \%$ for treated plants. After this period there was a reduction in percentage up to the 15 th day of treatment (22 and $35 \%$ respectively). The lowest results were seen for the control period of 0 days of thermotherapy (16 and 18\% respectively).

Similarly, Gama et al. (2012) observed that fennel seeds from plants treated with insecticide (TR) had better results than NT plants. Martins et al. (2006) however tested several insecticides, but observed no influence on the vigour of sorghum seeds when evaluated by first germination count.
Figure 5 - First germination count in stored seeds of Foeniculum vulgare, from plants treated (TR) and not treated (NT) with insecticide and submitted to different periods of thermotherapy

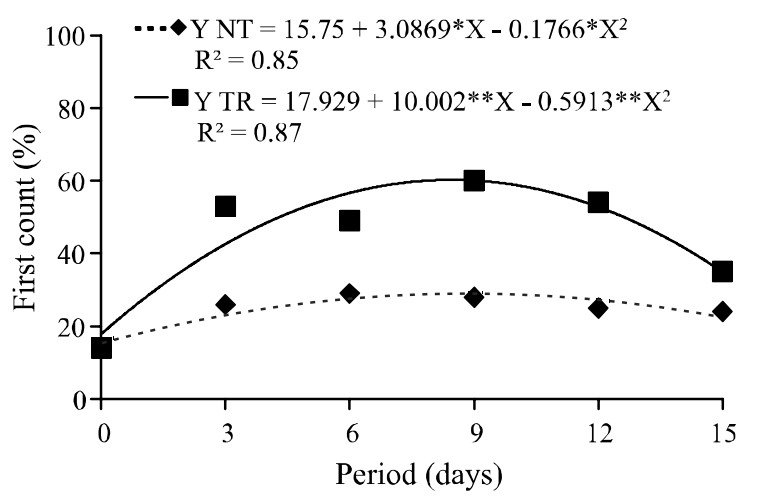

Figure 6 shows data for the speed of germination index (SGI). For this variable there was no significant interaction between conditions and periods of thermotherapy. Seeds from TR plants therefore exhibited a greater rate of germination compared to NT plants (1.92 and 1.15 respectively) (Figure 6A). In evaluating SGI throughout the period of thermotherapy, it can be seen that a quadratic model best fit the data, with an increase in the index up to the 8th day, when the highest result (1.86) was seen (Figure 6B). After this period however, there was a reduction in the rate of germination up to the 15th day of treatment (1.27). The lowest rate for germination was recorded for the control period of 0 days of thermotherapy (1.08). Muniz (2001) commented that the speed of germination index in tomato seeds treated at $70^{\circ} \mathrm{C}$ over periods of $4,8,12$ and 15 days did not differ from that of the control.

For seedling length, there was no significant interaction between the factors tested (Figure 7). It can be seen that the seeds of treated plants (TR) produced larger seedlings (6.11) compared to those from the seeds of untreated plants (NT) (5.31) (Figure 7A).

Gama et al. (2012) found a positive influence on seedling length in fennel from the application of insecticide. These results indicate that the growth of seedlings may be greatly affected by pest infestation due to immediate damage during seed development, as confirmed by several authors (BARBOSA et al., 2002; OLIVEIRA et al., 2007; PLAZAS et al., 2003), and that such damage can be reduced by adopting an efficient system of control.

Throughout the period of thermotherapy, an increase in seedling length can be seen up to the 12 th day, when the highest result was recorded $(6.74 \mathrm{~cm})$. After this period there was a small reduction in length 
Figure 6 - Speed of germination index (SGI) in stored seeds of Foeniculum vulgare, from plants treated (TR) and not treated (NT) with insecticide and submitted to different periods of thermotherapy (B)
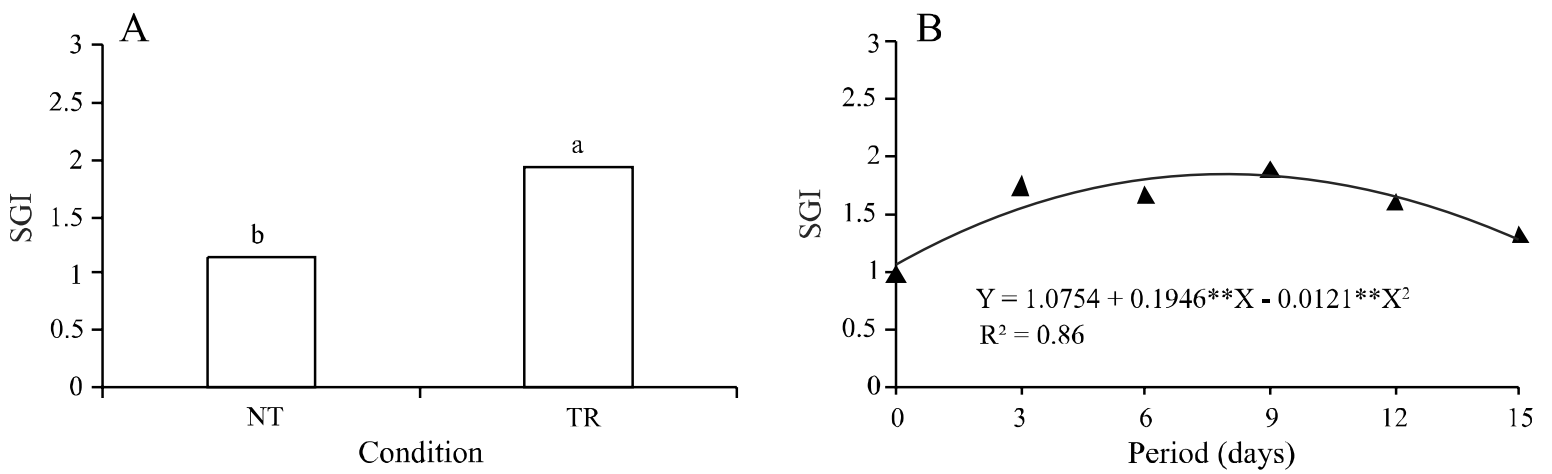

Figure 7 - Length of seedlings of Foeniculum vulgare from the stored seeds of plants treated (TR) and not treated (NT) with insecticide (A) and submitted to different periods of thermotherapy (B)

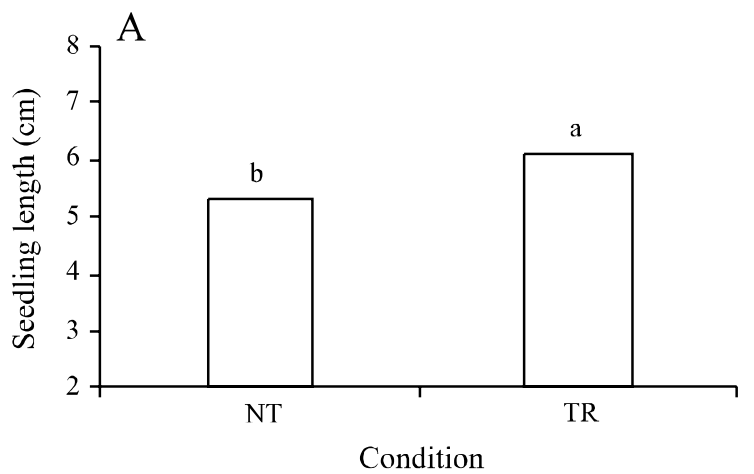

up to the 15 th day of treatment $(6.58 \mathrm{~cm})$, with the smallest value being observed for the control period of 0 days of thermotherapy $(3.57 \mathrm{~cm})$ (Figure 7B).

For seedling dry weight (Figure 8), the highest values were found in seeds produced by TR plants for all periods of heat exposure. For the conditions NT and $\mathrm{TR}$, there was an increase in dry weight up to 7.5 and 8.0 days respectively, when the greatest values were seen (3.43 and $5.36 \mathrm{mg}$ respectively). After this period there was a reduction in dry weight until the 15 th day (0.98 and $3.44 \mathrm{mg}$ respectively). The lowest values however were recorded for the control period of 0 days of thermotherapy ( 0.97 and $2.84 \mathrm{mg}$ respectively). On the other hand, Gama et al. (2012) found no difference in the dry weight of fennel seedlings from plants, whether treated or not treated with the insecticide thiamethoxam during storage.

The results of this work show that there are good prospects for the use of heat treatment in reducing the incidence of Alternaria sp. in fennel seeds. From an

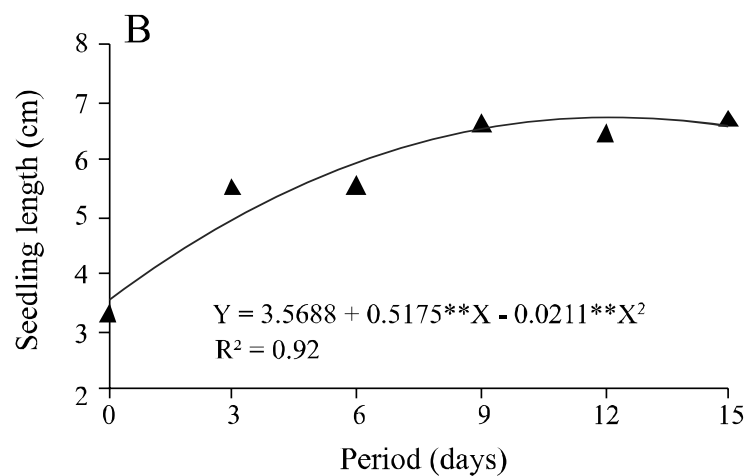

environmental standpoint, the method is non-polluting and has no residual effects, and should be recommended for eradicating pathogens.

Figure 8 - Dry weight in seedlings of Foeniculum vulgare from the stored seeds of plants treated (TR) and not treated (NT) with insecticide and submitted to different periods of thermotherapy

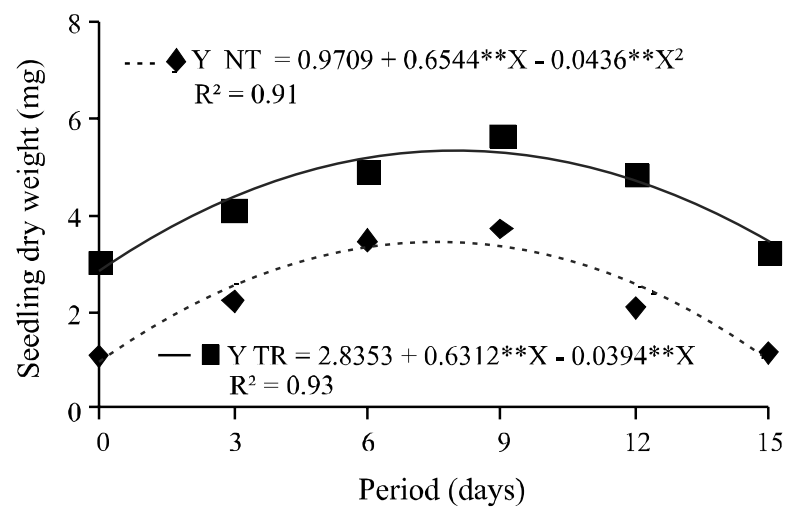




\section{CONCLUSIONS}

1. The cropping system has no influence on the incidence of the fungus Alternaria sp.;

2. Fennel seeds stored for three years, coming from plants treated with thiamethoxam, display better health and physiological quality;

3. Thermotherapy for 12 days at $70{ }^{\circ} \mathrm{C}$ reduces the incidence of Alternaria sp., without causing damage to the physiological quality of the fennel seeds.

\section{REFERENCES}

BARBOSA, F. R. et al. Controle do caruncho-do-feijoeiro Zabrotes subfasciatus com óleos vegetais, munha, materiais inertes e malathion. Pesquisa Agropecuária Brasileira, v. 37, n. 9, p. 1213-1217, 2002.

BRAGA, M. P. et al. Relações entre tratamento térmico, germinação, vigor e sanidade de sementes de tomate. Revista Brasileira de Sementes, v. 32, n. 1, p. 101-110, 2010.

BRASIL. Ministério da Agricultura, Pecuária e Abastecimento Regras para análise de sementes. Brasília: SNDP/DNDV/ CLAV, 2009. 399 p.

CARMO, M. G. F. et al. Tratamentos de erradicação de Xanthomonas vesicatoria e efeitos sobre a qualidade das sementes de tomate. Horticultura Brasileira, v. 22, n. 3, p. 579-584, 2004.

CHOI, E. M.; HWANG, J. K. Antiinflammatory, analgesic and antioxidant activities of the fruit of Foeniculum vulgare. Fitoterapia, v. 75, n. 6, p. 557-565, 2004.

COUTINHO W. M. et al. Qualidade sanitária e fisiológica de sementes de milho submetidas à termoterapia e condicionamento fisiológico. Fitopatologia Brasileira, v. 32, n. 6, p. 458-464, 2007.

ESTEFANI, R. C. C.; MIRANDA FILHO, R. J.; UESUGI, C. H. Tratamentos térmico e químico de sementes de feijoeiro: eficiência na erradicação de Curtobacterium flaccumfaciens pv. flaccumfaciens e efeitos na qualidade fisiológica das sementes. Fitopatologia Brasileira, v. 32, n. 6, p. 434-438, 2007.

GAMA, J. S. N. et al. Qualidade fisiológica e sanitária de sementes de erva-doce (Foeniculum vulgare Mill.) armazenadas. Revista Brasileira de Plantas Medicinais, v. 14, p. 175-182, 2012. Número Especial.

LAZAROTTO, M. et al. Tratamento de sementes de canafístula via calor úmido. Revista de Ciências Agrárias, v. 56, n. 3 , p. $268-273,2013$.

LOPES, F. S.; ROSSETTO, C. A. V. Qualidade de sementes de tomate influenciada pelos tratamentos térmico e osmótico. Horticultura Brasileira, v. 22, n. 3, p. 642-646, 2004.
MAGUIRE, J. D. Speed of germination-aid seedling emergence and vigor. Crop Science, v. 2, n. 2, p. 176-177, 1962.

MARTINS, C. C.; NAKAGAWA, J.; MARTINS, D. Seletividade de herbicidas sobre a produtividade e a qualidade de sementes de sorgo granífero. Agropecuária Técnica, v. 27, n. 1, p. 37-42, 2006.

MENDES, M. A. S. et al. Erradicação de Fusarium oxysporum em sementes de alfafa utilizando termo e quimioterapia. Fitopatologia Brasileira, v. 26, n. 2, p. 148-152, 2001.

MUNIZ, M. F. B. Controle de microrganismos associados às sementes de tomate (Lycopersicon esculentum L.) através do calor seco. Revista Brasileira de Sementes, v. 23, n. 1, p. 276280, 2001.

NEEGAARD, P. Seed pathology. London: The MacMillian, 1977. $839 \mathrm{p}$.

OLIVEIRA, I. R. et al. Bicudo e lagarta-rosada em algodoeiros no sertão sergipano. Aracaju: Embrapa Tabuleiros Costeiros, 2007.

OLIVEIRA, M. D. M. et al. Tratamentos térmicos e químicos em sementes de Mulungu e efeitos sobre a qualidade sanitária de fisiológica. Revista Caatinga, v. 22, n. 3, p. 150-155, 2009.

OLIVEIRA, M. D. M. et al. Qualidade sanitária e fisiológica de sementes de Amburana cearensis A.C. Smith submetidas à termoterapia e tratamento químico. Acta Scientiarum. Agronomy, v. 33, n. 1, p. 45-50, 2011.

PEDROSO, D. C. et al. Métodos de inoculação de Alternaria alternata e A. dauci em sementes de salsa e sua influência na qualidade fisiológica. Revista Brasileira de Sementes, v. 32, n. 3, p. 79-85, 2010.

PLAZAS, I. H. A. Z.; MEDINA, P. F.; NOVO, J. P. S. Viabilidade de sementes de trigo tratadas com fenitrotion e infestadas por Sitophilus oryzae (L.) (Coleoptera: Curculionidae) durante o armazenamento. Bragantia, v. 62, n. 2, p. 315-327, 2003.

REIS, A. et al. Associação de Alternaria dauci e A. alternata com sementes de coentro e eficiência do tratamento químico. Horticultura Brasileira, v. 24, n. 1, p. 107-111, 2006.

SILVA, A. M. S. et al. Termoterapia via calor seco no tratamento de sementes de tomate: eficiência na erradicação de Xanthomonas campestris pv. vesicatoria e efeitos sobre a semente. Fitopatologia Brasileira, v. 27, n. 6, p. 586-593, 2002.

SOUSA, L. A. et al. Sazonalidade dos ductos secretores e óleo essencial de Foeniculum vulgare var. vulgare Mill. (Apiaceae). Revista Brasileira de Farmacognosia, v. 15, n. 2, p. 155-161, 2005.

TRIGO, M. F. O. O. et al. Tratamento térmico em sementes de cenoura. Pesquisa Agropecuária Brasileira, v. 33, n. 1, p. 357-361, 1998a.

TRIGO, M. F. O. O. et al. Efeito da pré-secagem sobre o desempenho de sementes de cenoura na termoterapia. Revista Brasileira de Sementes, v. 20, n. 1, p. 43-47, 1998b. 